\title{
Intelligent Capital, Organizational Learning, and Corporate Performance Influence Relationship
}

\author{
Li-Wei Lin ${ }^{D},{ }^{1}$ Su-Mei Gan, ${ }^{1}$ and Shih-Yung Wei ${ }^{2}{ }^{2}$ \\ ${ }^{1}$ School of Information, Zhejiang University of Finance and Economics Dongfang College, Zhejiang, China \\ ${ }^{2}$ Business School of Yulin Normal University, Yulin, China \\ Correspondence should be addressed to Shih-Yung Wei; 2057085290@qq.com
}

Received 14 June 2021; Revised 5 September 2021; Accepted 31 January 2022; Published 22 February 2022

Academic Editor: C. H. Wang

Copyright (c) $2022 \mathrm{Li}-$ Wei Lin et al. This is an open access article distributed under the Creative Commons Attribution License, which permits unrestricted use, distribution, and reproduction in any medium, provided the original work is properly cited.

Purpose. The purpose of this paper is to examine the factors influencing intelligent capital on enterprise performance. Design/ Methodology/Approach. Based on dynamic panel data of listed companies in the Taiwan electronics industry from 2006 to 2017, we used the GMM estimation method. Findings. The findings of this study indicate that human capital, innovation capital, process capital, and customer capital all significantly improve enterprise performance through the mechanism of organizational learning. Research Limitations/Implications. Future research on cross-country studies of various forms of electronics industry would be worth conducting to determine regional differences in the development of electronics industry activities. Originality/Value. The empirical results demonstrate that human capital, process capital, and customer capital exert a significant promoting effect on enterprise performance, while innovation capital significantly inhibits improvement of enterprise performance.

\section{Introduction}

Our research focuses on the combination of cross-fields, including psychology, management, and organizational behavior to break the previous academically insufficient knowledge areas. Our research purpose is mainly to examine the factors influencing intelligent capital on enterprise performance. Taiwan's electronics industry needs to continuously transform its enterprises and generate performance, and it needs to continuously improve its own intangible asset capabilities.

With the rapid development of the knowledge economy and increasingly intense market competition, enterprises need to continually acquire new knowledge and skills through organizational learning, thereby optimizing enterprise resource allocation and achieving profitable growth. However, great differences exist among enterprises in organizational learning ability, which will influence the effect of intellectual capital in creating value and promoting enterprise performance. As an important source for enterprises to gain competitive advantages, intelligent capital has constituted a topic of broad focus for scholars [1-6].
The economist Galbraith first proposed the concept of intelligent capital in 1969. He asserted that intelligent capital constituted an act of using brainpower, and not knowledge only, which indicated that intelligent capital was a form of value creation. Thus far, however, no consensus exists on the definition of intelligent capital in the extant literature. Guenther and Beyer [7] believed that intelligent capital is the sum of all of the intangible assets of an enterprise, including technology, customer information, trademark rights, ethics, and corporate culture. Subramnniam and Youndt [8], on the other hand, proposed that intelligent capital comprises all of the knowledge that can bring a competitive advantage to enterprises, and which can provide enterprises with methods to accumulate and utilize knowledge. Iswati and Anshori [9] contended that intelligent capital was the difference between market value and book value, which was expressed as the average of the five-year market value minus the average of the book value.

Since entering the new economic era, many companies have invested heavily in employee training, research and development, customer information, data management, and other key aspects. These forms of intelligent capital 
constitute strategic resources for enterprises and are also the key for them to obtain sustained competitive advantages, which directly affects enterprise performance. Indeed, Ahmed [10], Chen et al. [11], and Sardo et al. [12] have demonstrated a significant positive relationship between intellectual capital and enterprise performance. However, some scholars have reached the opposite conclusion. For example, Firer and Mitchell Williams [13] reported a significant correlation between physical capital and enterprise performance but no empirical evidence of a significant association between intelligent capital and enterprise performance. Indeed, a consensus has not yet been attained concerning the influence of intelligent capital on enterprise performance, and the relationship between the two remains to be elucidated.

In addition, the empirical results of Hsu and Fang [14], based on data of the Taiwan integrated circuit design industry, show that intelligent capital is closely related to organizational learning and plays an important role in enterprise innovation performance through the mechanism of organizational learning. Soo et al. [15] also reported that intelligent capital would exert a positive impact on the innovation performance of enterprises through their absorptive capacity.

Most of the above researches utilized the least square method to estimate the effect of intelligent capital on enterprise performance without considering the dynamic influence of enterprise performance. In fact, the corporate performance of the current period is often related to that of the previous period. Therefore, this paper takes listed companies that are highly dependent on intelligent capital in the Taiwan electronics industry as the research object. A dynamic panel model is introduced to describe the dynamic behavior of enterprise performance. In order to eliminate the influence of endogeneity, the GMM method is used to estimate model parameters, accurately evaluate the influence of intelligent capital on enterprise performance, and empirically test the mediating effect of organizational learning on the influence of intelligent capital on enterprise performance. We use learning theory. Organizational learning can be achieved through (1) behaviorism, (2) cognitivism, (3) constructivism, and (4) humanism to further achieve the learning and sharing of knowledge throughout the organization.

Our research contributions are mainly able to enhance the sustainable operation and profitability of Taiwan's electronics industry in terms of company performance and improve overall operating performance through the emphasis on intangible asset capabilities.

\section{Theoretical Analysis and Research Hypothesis}

2.1. Intelligent Capital and Enterprise Performance. Salehi and Zimon [16] refer to intellectual capital and board characteristics as key factors in establishing value creation and growth. According to knowledge management theory, intelligent capital is the sum of knowledge resources that can enable enterprises to realize the market value and asset appreciation. These knowledge resources are usually formed in the production and management activities of enterprises. Edvinsson and Malong [17] measured intelligent capital from the three dimensions of human capital, structured capital, and customer capital, among which structured capital was subdivided into innovation capital and process capital. Based on this perspective, intelligent capital is divided into the following four basic elements: (1) human capital, (2) innovation capital, (3) process capital, and (4) customer capital. Salehi and Zimon [16] refer to assess the impact of intellectual capital, such as human capital (HC), structural capital (SC), relational capital (RC), and customer capital (CC).

Human capital refers to the knowledge, skills, and experience of employees and managers. The accumulation of human capital is a critical source of enterprise competitiveness. The cognitive ability and adaptability of employees enable them to master requisite professional knowledge and skills and apply them to practical work in a timely manner. In this way, human capital can improve enterprise production efficiency, increase enterprise profits, and promote the improvement of enterprise performance. Dalwai and Salehi [18] refer to the influence of business strategy and intellectual capital on firm performance. Therefore, the following hypothesis is proposed:

Hypothesis 1A: human capital has a positive impact on enterprise performance.

Innovation capital refers to the enterprise's creativity, innovation achievements, and the potential for developing new products. Business innovation can improve production processes, shorten product production cycles, and increase efficiency per unit of output. However, in the short term, due to a large amount of funds necessary for research and development (R \& D) activities and that the effect of R \& D can be nonobvious, managers of enterprises generally tend to reduce $\mathrm{R} \& \mathrm{D}$ expenditure, which is not conducive to the improvement of enterprise performance. Therefore, the following hypothesis is proposed:

Hypothesis 1B: innovation capital has a negative impact on enterprise performance in the short term.

Process capital refers to the most effective working methods and processes formed after the long-term accumulation of knowledge invested by employees, including enterprise procedures, norms, and information systems. Process capital is conducive to enterprise information screening and organizational decision-making, reduction of the probability of similar misplacement, and augmentation of the efficiency of the utilization of resources, so as to promote the improvement of enterprise performance. Therefore, the following hypothesis is proposed:

Hypothesis 1C: process capital has a positive effect on business performance.

Customer capital refers to capital implied in an enterprise's reputation, customer satisfaction, and customer loyalty. Mutual trust between enterprises and 
suppliers can effectively prevent the occurrence of fraud and reduce transaction costs. In addition, close cooperation between enterprises and banks can decrease the cost and risk of technological innovation. A good relationship between enterprises and the government can also assist enterprises to obtain internal resources and preferential policies, thus decreasing the cost of acquiring scarce resources. Maintaining good relationships with customers, suppliers, and governments facilitates reducing enterprise costs and improving enterprise performance. Therefore, the following hypothesis is proposed:

Hypothesis 1D: customer capital has a positive impact on business performance.

2.2. The Mediating Role of Organizational Learning. Senge [19] asserts that all enterprises are learning organizations, but great differences exist in the breadth and depth of organizational learning, which will affect the functions of intangible assets of enterprises, especially the role of intelligent capital value based on knowledge. Organizational learning can promote the transmission of explicit and implicit knowledge, cultivate and develop enterprise capabilities, promote technological innovation and management innovation, reduce enterprise costs and obtain more profits, and thus promote the improvement of enterprise performance.

Overall, as an important intangible asset, intelligent capital plays an essential role in improving enterprise performance. Organizational learning broadens the knowledge base of enterprises, assists enterprises to integrate resources and augments the utilization efficiency of intangible assets, and thus improves enterprise performance. Therefore, the following hypotheses are proposed:

Hypothesis 2A: human capital will promote enterprise performance through organizational learning

Hypothesis 2B: innovation capital will promote enterprise performance through organizational learning

Hypothesis 2C: process capital will promote enterprise performance through organizational learning

Hypothesis 2D: Customer capital will promote enterprise performance through organizational learning

We can see from Figure 1 the relationship of the entire learning organization theory to the electronic industry.

\section{Study Design}

3.1. Model Specification. Considering that enterprise performance may have a certain dynamic hysteresis, that is, the current enterprise performance will be affected by the previous one [24-26] we are mainly looking at the data situation of this issue and the situation of the next issue, there is no problem with the sentence, [27], and the specific form is set as follows:

(1) Enterprise performance; intelligent capital (including human capital, innovation capital, process capital, and customer capital), other control variables affecting enterprise performance, individual nonobserved effect, and random disturbance term.

In addition, according to the above research hypothesis, intelligent capital will have an impact on enterprise performance through organizational learning. In order to verify the existence of this mechanism, the following model is constructed in this paper:

(2) The intermediary variable is the proxy variable reflecting organizational learning, and the intermediary effect of intelligent capital on enterprise performance can be determined according to the sign of the estimated coefficient and its significance.

Considering that explanatory variables in the dynamic panel model contain lagged dependent variables, explanatory variables will be correlated with random disturbance terms, resulting in endogeneity problems. If the OLS method is used to estimate directly, the estimated coefficients obtained are both biased and inconsistent, even if the in-group estimator (fixed-effects method) is adopted. For panel data with a small number of individuals and a large number of periods, the consistent estimator can be obtained by correcting the deviation. The sample data in this paper, however, constitute short panel data with a large number of individuals and a relatively short number of periods.

To solve the endogeneity problem in dynamic panels, Arellano and Bover [28] suggest the utilization of generalized moment estimation (GMM). However, the differential generalized moment estimation method (DIF-GMM) still possesses the problem of weak instrumental variables. Therefore, Blundell and Bond [29] adopted the system moment estimation method (SYs-GMM) to estimate the dynamic panel model. Compared with DIF-GMM, SYsGMM is more efficient because it can use both the level value of explanatory variables and the first-order difference value as instrumental variables. The validity of the instrumental variable requires the use of the Arellano-Bond test ( $\mathrm{AB}$ test). Only the existence of second-order autocorrelation in the $\mathrm{AB}$ test can indicate that the instrumental variable is reasonable and effective. It is also necessary to use the Hansen test to assess the overidentification constraint of instrumental variables, and acceptance of the null hypothesis indicates that the setting of instrumental variables is appropriate. Considering the characteristics of the sample data in this paper, we mainly use SYs-GMM to estimate model parameters.

3.2. Variable Declaration. The empirical study of this paper mainly involves the following four types of variables: (1) explained variables, (2) core explanatory variables, (3) intermediary variables, and (4) control variables.

3.3. Model Setting and Variable Selection. In learning theory, the difference between the market value of a firm and its book value is highly correlated with smart capital [30, 31]. This chapter measures intelligent capital by four dimensions: 


\begin{tabular}{|c|c|c|c|c|}
\hline $\begin{array}{l}\text { Illustrative } \\
\text { research }\end{array}$ & Context & $\begin{array}{l}\text { Theoretical } \\
\text { basis }\end{array}$ & $\begin{array}{l}\text { Antecedents to } \\
\text { learning } \\
\text { organization } \\
\text { in electronics } \\
\text { industry }\end{array}$ & $\begin{array}{l}\text { Key findings or } \\
\text { propositions }\end{array}$ \\
\hline $\begin{array}{l}\text { Peter Senge } \\
{[20]}\end{array}$ & $\begin{array}{l}\text { Between Learning } \\
\text { Organization }\end{array}$ & $\begin{array}{l}\text { Learning } \\
\text { organization } \\
\text { theory }\end{array}$ & $\begin{array}{l}\text { Lifelong } \\
\text { learning, } \\
\text { continuous self- } \\
\text { organization } \\
\text { and } \\
\text { reconstruction } \\
\text { to maintain } \\
\text { competitiveness }\end{array}$ & $\begin{array}{l}\text { The findings } \\
\text { suggest that } \\
\text { Organizations } \\
\text { should strive } \\
\text { for simplicity, } \\
\text { flatness, } \\
\text { flexibility, } \\
\text { lifelong } \\
\text { learning, and } \\
\text { continuous self- } \\
\text { organization to } \\
\text { maintain } \\
\text { competition }\end{array}$ \\
\hline $\begin{array}{l}\text { Wolfgang } \\
\text { Köhle[21] }\end{array}$ & cognitive structure & $\begin{array}{l}\text { Latent } \\
\text { learning } \\
\text { theory }\end{array}$ & $\begin{array}{l}\text { Learners use } \\
\text { the cognitive } \\
\text { process to store } \\
\text { and organize } \\
\text { various data to } \\
\text { form a } \\
\text { cognitive } \\
\text { structure. }\end{array}$ & $\begin{array}{l}\text { The findings } \\
\text { suggest that } \\
\text { Organizations } \\
\text { Cognitive } \\
\text { school is a } \\
\text { learning theory, } \\
\text { as opposed to } \\
\text { the theory of } \\
\text { behaviorist } \\
\text { school }\end{array}$ \\
\hline Huber[22] & Adaptive & $\begin{array}{l}\text { Organization } \\
\text { learning } \\
\text { theory }\end{array}$ & $\begin{array}{l}\text { Organizational } \\
\text { learning has } \\
\text { four main } \\
\text { elements: } \\
\text { knowledge } \\
\text { acquisition, } \\
\text { information } \\
\text { distribution, } \\
\text { information } \\
\text { interpretation } \\
\text { and } \\
\text { organizational } \\
\text { memory }\end{array}$ & $\begin{array}{l}\text { The findings } \\
\text { suggest that } \\
\text { Innovation, } \\
\text { Team, } \\
\text { Learning, } \\
\text { Sharing, } \\
\text { Passion and } \\
\text { Realization are } \\
\text { also goals that } \\
\text { leaders must } \\
\text { guide members } \\
\text { towards }\end{array}$ \\
\hline $\begin{array}{l}\text { Levitt \& } \\
\text { March } \\
{[23]}\end{array}$ & $\begin{array}{l}\text { "Stimulus- } \\
\text { response" } \\
\text { behavioral } \\
\text { adaptation model }\end{array}$ & $\begin{array}{l}\text { Organization } \\
\text { learning } \\
\text { theory }\end{array}$ & $\begin{array}{l}\text { Organizational } \\
\text { learning as a } \\
\text { process for the } \\
\text { organization to } \\
\text { adapt to the } \\
\text { external } \\
\text { environment }\end{array}$ & $\begin{array}{l}\text { The findings } \\
\text { suggest that } \\
\text { involved in } \\
\text { social } \\
\text { cognition, } \\
\text { psychological } \\
\text { changes }\end{array}$ \\
\hline
\end{tabular}

Figure 1: Illustrative research summarizing the antecedents to learning organization in the electronics industry.

human capital, innovation capital, process capital, and customer capital. By establishing the difference between market value and book value and the regression equation of intelligent capital, this paper comprehensively examines the difference between the net value and value of intelligent capital to the enterprise market. The existing research literature shows that the current market value and value difference of the enterprise market are usually related to the past. Therefore, this paper uses the dynamic panel model including the lagging dependent variable to evaluate the effect of intelligent capital on the difference between the net market value and the value of the enterprise. Considering that the explanatory variables in the dynamic panel model contain hysteresis dependent variables, the explanatory variables are related to the random disturbance terms, resulting in endogeneity problems. If the OLS method is used for estimation directly, even if the estimated coefficients obtained in the large sample case are biased inconsistently, in order to solve the endogeneity problem existing in the model, we use the GMM method to estimate. 
The setting of the empirical model in this chapter is carried out according to the following operational procedures:

3.3.1. Testing the Dynamic Relationship. It is necessary to test the regression equation to prove that it is necessary to add the lag term of the interpreted variable to the regression model. For the related research and discussion of the difference between the net value and the value of the enterprise, there are two reasons for adding the lag term of the dependent variable in the regression model. First, because the company's net worth and value are usually related to the past, if you do not consider the impact of the past on the present, there will be a problem of missing variables, which will bring the wrong form of the model. Second, if the GMM method is used for estimation in subsequent evidence, and the lag term of the explanatory variable is used as the tool variable for estimation; the lag order of the dependent variable is determined. The lag order of the dependent variable is determined by the regression equation of the following type:

Tobin $Q_{i t}=\alpha_{0}+\sum \alpha_{p} *$ Tobin $Q_{i, t-p}+$ Controls $+\varepsilon_{i t}$,

where TobinQ_it represents the difference between the company's net worth and value in the current period. Tobin $Q(i, t-p)$ represents the difference between the net value and value of the enterprise in the first, second, and third phases. Controls indicate the size of the enterprise. Control variables include enterprise age, debt ratio, asset growth rate, and director-supervisor ratio. In formula (1), the intelligent capital variable is not added yet, and the model estimates use three different methods: OLS, fixed effect, and random effect.

3.3.2. Testing Endogenous Problems. The regression equation is used to illustrate the influence of the interpreted variable on the explanatory variable, and the endogenous problem existing in the model is determined. We are endogenous in the process of studying the difference between intelligent capital and enterprise value and value. In general, the source of endogenous nature mainly includes the following three aspects.

First is the problem of missing variables. In order to solve the endogeneity problem caused by missing variables, this paper eliminates the influence of other factors on Tobin $Q$ by adding control variables and adds the lag term of the dependent variable to reduce the possibility of model mis-set.

Second is the problem of unobservable variables. Since some influencing factors cannot be observed, this will also bring endogenous problems to the model. But these unobservable factors are usually some of the characteristics that reflect the individual. In order to capture these unobservable individual characteristics, the model is set to

$$
\text { Tobin }_{i t}=\alpha+\beta \text { Tobin }_{i, t-1}+\gamma X_{i t}+\lambda Z_{i t}+\eta_{i}+\varepsilon_{i t},
$$

where the individual heterogeneity variable $\eta_{-} i$ is included, and the residual term is $\varepsilon_{-}$it, and there is a correlation between the two. If the OLS method is used to estimate formula (2), the estimation will be inconsistent because of the endogeneity. Therefore, we finally solve the effect of individual heterogeneity on the whole regression through the fixed-effect method.

Third is the problem of two-way causality. While the dependent variable can be interpreted by the independent variable, the independent variable can also be interpreted by the dependent variable, that is, there is a causal relationship between the variables, which will lead to the endogeneity of the model. The following equation clearly reflects the relationship between the independent variable and the dependent variable lag term:

$$
X_{i t}=f\left(\text { TobinQ }_{i, t-1}, Z_{i t}, \eta_{i}, \varepsilon_{i t}\right),
$$

where $X_{i t}$ represents the explanatory variables, namely, innovation capital, human capital, process capital, and customer capital variables; Tobin $Q_{i, t-1}$ represents the difference between the net value and the value of the enterprise in the first period of the lag; $Z_{i t}$ represents the control variable; and $\eta_{i}$ represents the individual heterogeneity of the company. It is easy to know from equation (2) that (Tobin $_{i, t-1}$ ) can also be interpreted by the individual heterogeneity $\eta_{i}$, resulting in the explanatory variable in equation (3) Tobin $Q_{i, t-1}$ is associated with a random disturbance term $\left(\varepsilon_{i t}\right)$, resulting in an endogeneity problem. If estimates are made directly using OLS or fixed-effect methods, consistent estimates cannot be obtained even in large sample cases. To test for endogenous problems caused by two-way causality in the model, we set the following equation:

$$
X_{i t}=\alpha+\beta \text { TobinQ }_{i, t-1}+\text { Controls }+\varepsilon_{i t},
$$

where $X_{i t}$ represents intelligent capital, including innovation capital, human capital, process capital, and customer capital; Tobin $Q_{i, t-1}$ represents the difference between the company's net value and value in the first period; and Controls represents control variables. In this paper, formula (4) is estimated by OLS, fixed-effect, random-effect, and other methods to test whether there is an endogeneity problem caused by two-way causality.

\subsubsection{Model Construction and Parameter Estimation. In} view of the fact that the impact of intelligent capital on TobinQ may be lagging behind, this paper adds the lag term of human capital, innovation capital, process capital, and customer capital in the regression equation. Mainly this equation is setting and predicting, so it needs to be judged.

Before using the GMM method to estimate the dynamic panel model, it is also necessary to determine the lag order of the intelligent capital affecting TobinQ. This paper first uses OLS, fixed-effects, random-effects, and other estimation methods to determine the lag order of human capital, innovation capital, process capital, customer capital, and other intelligent capital variables. The specific regression equation is set as follows: 
Tobin $_{i t}=\alpha+\beta \operatorname{Tobin}_{i, t-1}+\gamma \sum_{p} X_{i, t-p}+\lambda Z_{i t}+\eta_{i}+\varepsilon_{i t}$,

where $\mathrm{Tobin}_{i t}$ and $\mathrm{Tobin}_{i, t-1}$, respectively, represent the difference between the net value and the value of the current period and the lag period; $X_{i, t-p}$ indicates the lag 0-3 period; the intelligent capital variable, $Z_{i t}$ represents other control variables that affect the difference between the firm's net worth and value; $\eta_{i}$ represents the individual heterogeneity of the firm; and $\varepsilon_{i t}$ represents the random disturbance term.

For dynamic panel data, even within the group estimator (fixed-effect method), it is inconsistent (Nickell, 1981). For panel data with a small number of individuals and a large number of periods, a consistent estimator can be obtained by correcting the deviation. However, the sample data in this paper belongs to short panel data with a large number of individuals and a relatively short period of time. Therefore, the system GMM method will be used for estimation.

Blundell and Bond [29] used differential GMM equations and horizontal GMM equations as an equation system for GMM estimation, referred to as "system GMM." Compared with the differential GMM, the system GMM has higher efficiency because it can simultaneously use the horizontal value of the explanatory variable and the firstorder difference value as the tool variables. The equations of the system GMM are shown in the following equations:

$$
\begin{gathered}
\text { Tobin }_{i t}=\alpha+\beta \text { Tobin }_{i, t-1}+\gamma X_{i t}+\lambda Z_{i t}+\eta_{i}+\varepsilon_{i t}, \\
\Delta \text { Tobin }_{i t}=\alpha+\beta \Delta \text { Tobin }_{i, t-1}+\gamma \Delta X_{i t}+\lambda Z_{i t}+\varepsilon_{i t} .
\end{gathered}
$$

At the same time, the difference sequence $\left\{\Delta\right.$ Tobin $_{i, t-1}, \Delta$ Tobin $\left._{i, t-2}, \ldots\right\}$ and the horizontal sequence $\left\{\Delta\right.$ Tobin $_{i, t-1}, \Delta$ Tobin $\left._{i, t-2}, \ldots\right\}$ are used as a tool variable of Tobin $Q_{i, t-1}$ to estimate equation (6) to obtain an unbiased and consistent estimator.

The variables in the empirical study are divided into three categories: explanatory variables, explanatory variables, and control variables.

(1) Explained Variable: Enterprise Performance. Smart capital may exert both long- and short-term effects on enterprise performance. In order to use a single performance indicator to measure the short- and long-term impact, this paper employs Tobin Q, which is derived from the timevarying measurement method based on market value, to determine the market value of enterprises. It is taken as a measurement index of enterprise value and is obtained by dividing the market value of assets by the book value of assets.

(2) Core Explanatory Variable: Intelligent Capital. This paper reflects intelligent capital from four dimensions: human capital, which is expressed by the logarithm of the number of employees plus one; innovation capital, which is expressed by the R \& D intensity of the company, is the ratio of R \& D expenses to operating income; process capital, which is measured by the added value of each employee in the enterprise, is the ratio of after-tax net profit to the total number of employees; and customer capital, which is represented by the ratio of marketing expenses, that is, the ratio of marketing expenses to operating income.

(3) Intermediary Variable: Organizational Learning. Based on the research framework of Teece et al. [32], the standardized mean values of total assets, total profits, and revenue growth rate were selected as measurement indicators of organizational learning ability.

(4) Control Index. Factors affecting enterprise performance other than intelligent capital are regarded as control variables. According to relevant literature of previous enterprise performance theory, five variables are selected: (1) enterprise scale, which is measured by the natural logarithm of total enterprise assets; (2) the age of the enterprise, which can be obtained by subtracting the date of establishment of the company from the date of the financial statement at the end of the current year; (3) the debt ratio, which is measured by the percentage of the total liabilities of the enterprise in the total assets of the enterprise; (4) the growth rate of assets, which is measured by the growth rate of the original value of fixed assets; and (5) the proportion of the board of supervisors, which is measured by the percentage of the shares held by the board of supervisors in the total number of shares of the enterprise. By controlling these characteristic factors, the influence of intelligent capital on enterprise performance can be more accurately discerned.

3.4. Sample Selection and Data Sources. In this paper, listed companies in the electronics industry in Taiwan are selected as the research samples, and the period from 2006 to 2017 is taken as the sample interval to investigate the influence of intelligent capital on enterprise performance.

According to established practices of research methodology, the research samples in this paper are processed as follows: (1) sample companies with data missing are deleted; (2) sample companies whose financial data are obviously unreasonable are excluded; and (3) each variable is reduced by $1 \%$ to decrease the bias resultant from outliers to the estimated results. After screening the original samples in the above steps, a total of 7,776 sample observations in 12 years from 648 companies were finally obtained.

In terms of data sources, the financial data related to enterprises, the data related to intelligent capital, and the data of the board of directors are from the TEJ Asia-Pacific Financial Database or annual reports of shareholders' meetings.

The descriptive statistical results of each major variable are presented in Table 1.

\section{Empirical Results and Analysis}

\subsection{Analysis of the Influence of Intelligent Capital on Enterprise Performance}

4.1.1. Overall Impact Analysis. The results of the sys-GMM estimation formula (1) are shown in column (1) of Table 2. The model passes the AB test and the Hansen test, indicating that there is no problem of overidentification of 
instrumentals and that all instrumentals are both reasonable and effective.

According to the results in column (1) of Table 2, the estimated coefficients of human capital, process capital, and customer capital are significantly positive at the statistical level of $1 \%$, indicating that improving the levels of human capital, process capital, and customer capital can significantly promote the improvement of enterprise performance. Moreover, the estimated coefficient of innovation capital is significantly negative at the statistical level of $1 \%$, revealing that the increase of innovation capital exerts a restraining effect on enterprise performance in the short term. Therefore, hypotheses $1 \mathrm{~A}, 1 \mathrm{~B}, 1 \mathrm{C}$, and $1 \mathrm{D}$ are supported.

GMM estimators in the sample size are smaller when there is a weak instrumental variable or a proclivity towards bias exists. Consequently, the GMM estimation containing the dependent variable lag of mixed estimation model (POLS) and fixed-effect model (FE) estimators are compared. In addition, the coefficient of the dependent variable lag of GMM estimation only between two models corresponding to the estimated coefficient afterwards is reasonable. To this end, this paper reports the estimated results of dynamic POLS and dynamic FE in columns (2) and (3) of Table 2, respectively. Table 2 shows that the estimated coefficient of L. Tobin's Q in column (1) lies between that of L. Tobin's Q in column (2) and that of L. Tobin's Q in column (3). This demonstrates that the results of sys-GMM estimation in this paper have no significant deviation due to the selection of instrumental variables.

4.1.2. Robustness Test. In order to ensure the reliability of the estimated results, in addition to the measures of setting control variables and eliminating endogenous problems, the following robustness tests are carried out in this paper.

The first is to replace the human capital variable and define it by the logarithm of the employees' age. The second is to replace the innovation capital variable by the ratio of $\mathrm{R}$ \& D expenditure to total enterprise assets. The third is to replace the process capital variable, expressed by the productivity of each employee, that is, the net operating income divided by the number of employees, and then take the logarithm. The fourth is to replace the customer capital variable, measure the growth rate of marketing expenses, and carry out a regression test on the benchmark model again. The robustness test results of successively replacing human capital, innovation capital, process capital, and customer capital are shown in columns (1), (2), (3), and (4), respectively, of Table 3 .

As the results from Table 3 indicate, the instrumental variables of the model are reasonable and effective, and there are no excessive problems with identification. Moreover, intelligence capital and the estimated coefficient of control variables and significant results are essentially identical to those in Table 2. Specifically, human capital, process capital, and customer capital are shown to improve business performance, while innovation capital significantly inhibits enterprise performance. Indeed, these research conclusions remain robust.
4.2. Analysis of the Results of Different Industrial Chains. The conclusions from the above analysis indicate that intelligent capital has a significant impact on enterprise performance; however, this only reflects the average effect and ignores the heterogeneous impact on enterprises in different industrial chain links. Subsequently, this paper divides the electronics industry into up-, mid-, and downstream enterprises from the perspective of industrial chains. Midstream enterprises comprise electronic parts and optoelectronics and two other industries, and downstream enterprises include computers and peripherals, electronic channels, communication networks, information services, other electronics, and five other industries. All sample enterprises were divided into three subsamples according to the up-, mid-, and downstream, and the benchmark model was regressed. The empirical results are presented in columns (1), (2), and (3) of Table 4.

From the first (1) results listed in Table 4, human capital, innovation capital, and flow of capital in $1 \%$ of the estimated coefficient statistics level are significantly positive, and customer capital in 1\% of the estimated coefficient statistics level is significantly negative. In other words, augmenting the level of human capital, innovation capital, and the flow of capital is beneficial for the improvement of upstream enterprise performance, whereas customer capital has no effect on upstream enterprise performance. From the results of column (2), human capital and the flow of capital in 1\% of the estimated coefficient statistics level are significantly positive, while innovation capital estimated coefficient is at a statistically significant negative level. Moreover, $1 \%$ of the estimated coefficient statistics level for customer capital shows that it is beneficial, but this benefit is not statistically significant. Human capital and the flow of capital impart advantageous effects on the middle enterprise performance; innovation capital has a negative effect on middle enterprise performance; and customer capital exerts no impact on middle enterprise performance. In addition, from the results of column (3), human capital and the flow of capital in $1 \%$ of the estimated coefficient statistics level is significantly positive, and customer capital in $10 \%$ of the estimated coefficient statistics level is significantly positive. The innovation capital estimates of the coefficient are negative but insignificant. Furthermore, human capital, process capital, and customer capital have a promoting effect on the performance of downstream enterprises, but innovation capital imparts no effect on the performance of downstream enterprises.

In general, human capital and process capital have a significant promoting effect on the performance of up-, mid-, and downstream enterprises. The former has the greatest influence on midstream enterprises, while the latter has the greatest influence on downstream enterprises. Innovation capital also imparts a significant promoting effect on the performance of upstream enterprises and a significant restraining effect on the performance of midstream enterprises. In addition, an increase in customer capital will significantly improve the performance of downstream enterprises and significantly reduce the performance of upstream enterprises. 
TABle 1: Descriptive statistics of each variable.

\begin{tabular}{|c|c|c|c|c|c|c|c|}
\hline Variable types & Variable name & Symbol & Observations & Average & $\begin{array}{l}\text { Standard } \\
\text { deviation }\end{array}$ & $\begin{array}{l}\text { Minimum } \\
\text { value }\end{array}$ & $\begin{array}{l}\text { Maximum } \\
\text { value }\end{array}$ \\
\hline \multirow[t]{2}{*}{ Explained variable } & Enterprise performance & Tobin Q & 7,608 & 1.124 & 0.668 & 0.370 & 4.720 \\
\hline & Human capital & Human & 7,621 & 5.577 & 1.201 & 2.758 & 9.035 \\
\hline \multirow{3}{*}{$\begin{array}{l}\text { Explanatory } \\
\text { variable }\end{array}$} & Innovation capital & Innovation & 7,697 & 0.050 & 0.062 & 0.000 & 0.385 \\
\hline & Process capital & Process & 5,904 & 6.575 & 1.249 & 2.063 & 9.582 \\
\hline & Customer capital & Customer & 7,695 & 0.057 & 0.046 & 0.000 & 0.293 \\
\hline \multirow[t]{3}{*}{ Intervening variable } & Organizational learning & Learn & 7,620 & -0.0308 & 0.360 & -0.906 & 1.963 \\
\hline & Enterprise scale & Scale & 7,620 & 15.170 & 1.293 & 12.58 & 19.72 \\
\hline & Enterprise age & Age & 7,621 & 3.011 & 0.438 & 1.601 & 3.815 \\
\hline \multirow{3}{*}{ Control variables } & Debt ratio & Lev & 7,621 & 0.396 & 0.159 & 0.065 & 0.804 \\
\hline & Asset growth rate & Investment & 7,621 & 0.038 & 0.397 & -0.753 & 3.662 \\
\hline & $\begin{array}{l}\text { Proportion of directors and } \\
\text { supervisors }\end{array}$ & DS & 7,620 & 0.210 & 0.120 & 0.045 & 0.605 \\
\hline
\end{tabular}

Note. The descriptive statistics in the table are the results of a $1 \%$ indentation of the sample data.

TABLE 2: Benchmark regression results of smart capital on enterprise performance.

\begin{tabular}{|c|c|c|c|}
\hline & $(1)$ & $(2)$ & $(3)$ \\
\hline L. Tobin Q & $\begin{array}{c}0.271^{* * *} \\
(0.022)\end{array}$ & $\begin{array}{c}0.593^{* * *} \\
(0.011)\end{array}$ & $\begin{array}{c}0.267^{* * *} \\
(0.014)\end{array}$ \\
\hline Human & $\begin{array}{c}0.425^{* * *} \\
(0.071)\end{array}$ & $\begin{array}{c}0.133^{* * *} \\
(0.010)\end{array}$ & $\begin{array}{c}0.152^{* * *} \\
(0.024)\end{array}$ \\
\hline Innovation & $\begin{array}{c}-2.618^{* * *} \\
(0.958)\end{array}$ & $\begin{array}{c}0.416^{* * *} \\
(0.139)\end{array}$ & $\begin{array}{c}-2.658^{* * *} \\
(0.424)\end{array}$ \\
\hline Process & $\begin{array}{c}0.247^{* * *} \\
(0.024)\end{array}$ & $\begin{array}{c}0.123^{* * *} \\
(0.006)\end{array}$ & $\begin{array}{c}0.123^{* * *} \\
(0.008)\end{array}$ \\
\hline Customer & $\begin{array}{c}4.025^{* * *} \\
(1.551)\end{array}$ & $\begin{array}{c}0.014 \\
(0.152)\end{array}$ & $\begin{array}{c}-1.508^{* * *} \\
(0.393)\end{array}$ \\
\hline Scale & $\begin{array}{c}-0.620^{* * *} \\
(0.066)\end{array}$ & $\begin{array}{c}-0.143^{* * *} \\
(0.011)\end{array}$ & $\begin{array}{c}-0.214^{* * *} \\
(0.030)\end{array}$ \\
\hline Age & $\begin{array}{l}-0.158 \\
(0.172)\end{array}$ & $\begin{array}{c}-0.050^{* * *} \\
(0.015)\end{array}$ & $\begin{array}{c}-0.240^{* *} \\
(0.093)\end{array}$ \\
\hline Lev & $\begin{array}{c}-1.253^{* * *} \\
(0.328)\end{array}$ & $\begin{array}{c}-0.120^{* *} \\
(0.048)\end{array}$ & $\begin{array}{l}-0.118 \\
(0.092)\end{array}$ \\
\hline Investment & $\begin{array}{c}0.034 \\
(0.050)\end{array}$ & $\begin{array}{c}0.024 \\
(0.016)\end{array}$ & $\begin{array}{c}0.051^{* * *} \\
(0.016)\end{array}$ \\
\hline DS & $\begin{array}{c}-1.501^{* * *} \\
(0.548)\end{array}$ & $\begin{array}{l}-0.007 \\
(0.049)\end{array}$ & $\begin{array}{l}-0.093 \\
(0.132)\end{array}$ \\
\hline Estimation method & SYS-GMM & Dynamic POLS & Dynamic FE \\
\hline Observations & 4604 & 4604 & 4604 \\
\hline $\operatorname{AR}(1)$ & 0.000 & & \\
\hline $\operatorname{AR}(2)$ & 0.784 & & \\
\hline Hansen & 0.349 & & \\
\hline
\end{tabular}

Note. ${ }^{* * *},{ }^{* *}$, and ${ }^{*}$ represent significance levels of $1 \%, 5 \%$, and $10 \%$, respectively. The values in brackets are the standard deviations of the estimated coefficients, and the estimated results of constant terms are not reported, the same as Table 3.

4.3. Test of the Action Mechanism of Intelligent Capital Affecting Enterprise Performance. According to the above theoretical analysis, intelligent capital may influence enterprise performance through the mechanism of organizational learning. In order to further elucidate the action mechanism of intelligent capital on enterprise performance, the sys-GMM method is used to estimate model (2). The results of the empirical test of the mechanism of organizational learning are presented in Table 5.

According to the estimated findings shown in Table 5, the results of the $\mathrm{AB}$ test and the Hansen test reveal that there is no overidentification problem with instrumental variables, and the selected instrumental variables are both reasonable and effective.

The results in column (1) of Table 5 show that the estimated coefficients of Human and Human_Learn are both significantly positive at the $1 \%$ statistical level, indicating that human capital significantly improves business performance through organizational learning. The results in column (2) reveal that the estimated coefficients of Innovation and Innovation_Learn are significantly positive at the statistical level of $1 \%$, showing that innovation capital has a significant promoting effect on enterprise performance through organizational learning. The results in column (3) 
TABLE 3: Robustness test results.

\begin{tabular}{lcccc}
\hline & $(1)$ & $(2)$ & $(3)$ & $(4)$ \\
\hline L. Tobin's Q & $0.301^{* * *}$ & $0.278^{* * *}$ & $0.432^{* * *}$ & $0.211^{* * *}$ \\
& $(0.029)$ & $(0.026)$ & $(0.018)$ & $(0.028)$ \\
hu3 & $0.149^{*}$ & $0.447^{* * *}$ & $0.453^{* * *}$ & $0.556^{* * *}$ \\
& $(0.081)$ & $(0.073)$ & $(0.098)$ & $(0.087)$ \\
in1 & -1.315 & $-3.664^{* * *}$ & $-0.935^{*}$ & $-2.105^{* *}$ \\
& $(0.929)$ & $(1.291)$ & $(0.547)$ & $(1.021)$ \\
pr3 & $0.260^{* * *}$ & $0.282^{* * *}$ & $0.374^{* * *}$ & $0.269^{* * *}$ \\
& $(0.033)$ & $(0.031)$ & $(0.075)$ & $(0.028)$ \\
cu1 & $2.487^{* *}$ & $3.501^{* *}$ & $2.465^{* * *}$ & $0.383^{* * *}$ \\
& $(1.166)$ & $(1.429)$ & $(0.604)$ & $(0.117)$ \\
Scale & $-0.201^{* * *}$ & $-0.620^{* * *}$ & $-0.483^{* * *}$ & $-0.828^{* * *}$ \\
& $(0.057)$ & $(0.060)$ & $(0.098)$ & $(0.092)$ \\
Age & $-0.295^{*}$ & -0.230 & 0.192 & -0.027 \\
& $(0.164)$ & $(0.163)$ & $(0.125)$ & $(0.185)$ \\
Lev & $-1.815^{* * *}$ & $-1.059^{* * *}$ & $-1.574^{* * *}$ & $-1.579^{* * *}$ \\
& $(0.205)$ & $(0.273)$ & $(0.255)$ & $(0.362)$ \\
Investment & 0.049 & 0.069 & $0.255^{* * *}$ & $0.076^{*}$ \\
& $(0.052)$ & $(0.045)$ & $(0.053)$ & $(0.045)$ \\
DS & -0.223 & $-1.885^{* * *}$ & 0.019 & $-1.701^{* * *}$ \\
& $(0.500)$ & $(0.492)$ & $(0.425)$ & $(0.658)$ \\
\hline Observations & 4584 & 4583 & 5895 & 4523 \\
AR (1) & 0.000 & 0.000 & 0.000 & 0.000 \\
AR (2) & 0.694 & 0.845 & 0.318 & 0.797 \\
Hansen & 0.655 & 0.618 & 0.159 & 0.158 \\
\hline
\end{tabular}

TABLE 4: Industrial chain heterogeneity test results.

\begin{tabular}{lccc}
\hline & $(1)$ & $(2)$ & $(3)$ \\
\hline L. Tobin's Q & $0.449^{* * *}$ & $0.219^{* * *}$ & $0.317^{* * *}$ \\
& $(0.011)$ & $(0.033)$ & $(0.025)$ \\
Human & $0.276^{* * *}$ & $0.438^{* * *}$ & $0.362^{* * *}$ \\
& $(0.030)$ & $(0.114)$ & $(0.099)$ \\
Innovation & $3.739^{* * *}$ & $-2.722^{* * *}$ & -2.313 \\
& $(0.606)$ & $(0.972)$ & $(1.483)$ \\
Process & $0.166^{* * *}$ & $0.151^{* * *}$ & $0.172^{* * *}$ \\
& $(0.011)$ & $(0.034)$ & $(0.030)$ \\
Customer & $-5.637^{* * *}$ & 0.111 & $3.399^{*}$ \\
& $(0.431)$ & $(1.639)$ & $(1.791)$ \\
Scale & $-0.148^{* * *}$ & $-0.443^{* * *}$ & $-0.469^{* * *}$ \\
& $(0.035)$ & $(0.116)$ & $(0.111)$ \\
Age & $0.441^{* * *}$ & $-0.760^{* * *}$ & $-0.557^{* *}$ \\
& $(0.110)$ & $(0.229)$ & $(0.224)$ \\
Lev & $-2.007^{* * *}$ & $-1.507^{* * *}$ & $-1.389^{* * *}$ \\
& $(0.150)$ & $(0.399)$ & $(0.270)$ \\
Investment & 0.016 & $0.141^{*}$ & 0.084 \\
& $(0.020)$ & $(0.072)$ & $(0.064)$ \\
DS & $0.936^{* * *}$ & -0.240 & $-1.836^{* * *}$ \\
& $(0.172)$ & $(0.491)$ & $(0.592)$ \\
\hline Observations & 691 & 1973 & 1940 \\
AR (1) & 0.001 & 0.000 & 0.000 \\
AR (2) & 0.542 & 0.236 & 0.847 \\
Hansen & 0.285 & 0.200 & 0.778 \\
\hline
\end{tabular}

reveal that the estimated coefficients of Process and Process_Learn are both significantly positive at the $1 \%$ statistical level, indicating that process capital significantly promotes enterprise performance through organizational learning. The results in column (4) demonstrate that the estimated
TABLE 5: Organizational development mechanism test results of intelligent capital on enterprise performance.

\begin{tabular}{|c|c|c|c|c|}
\hline & $(1)$ & $(2)$ & (3) & $(4)$ \\
\hline L. Tobin's Q & $\begin{array}{c}0.361^{* * *} \\
(0.018)\end{array}$ & $\begin{array}{c}0.363^{* * *} \\
(0.019)\end{array}$ & $\begin{array}{c}0.301^{* * *} \\
(0.022)\end{array}$ & $\begin{array}{c}0.401^{* * *} \\
(0.019)\end{array}$ \\
\hline Human & $\begin{array}{c}0.195^{* * *} \\
(0.053)\end{array}$ & & & \\
\hline Human_Learn & $\begin{array}{c}0.118^{* * * *} \\
(0.008)\end{array}$ & & & \\
\hline Innovation & & $\begin{array}{c}1.741^{* * *} \\
(0.575)\end{array}$ & & \\
\hline Innovation_Learn & & $\begin{array}{c}10.590^{* * * *} \\
(0.665)\end{array}$ & & \\
\hline Process & & & $\begin{array}{c}0.169^{* * *} \\
(0.016)\end{array}$ & \\
\hline Process_Learn & & & $\begin{array}{c}0.044^{* * *} \\
(0.006)\end{array}$ & \\
\hline Customer & & & & $\begin{array}{c}2.183^{* * *} \\
(0.767)\end{array}$ \\
\hline Customer_Learn & & & & $\begin{array}{c}6.014^{* * * *} \\
(0.405)\end{array}$ \\
\hline Scale & $\begin{array}{c}-0.160^{* * *} \\
(0.054)\end{array}$ & $\begin{array}{c}-0.106^{* *} \\
(0.047)\end{array}$ & $\begin{array}{c}-0.216^{* * *} \\
(0.046)\end{array}$ & $\begin{array}{l}-0.020 \\
(0.045)\end{array}$ \\
\hline Age & $\begin{array}{c}0.368^{* * *} \\
(0.119)\end{array}$ & $\begin{array}{l}0.215^{*} \\
(0.119)\end{array}$ & $\begin{array}{c}0.050 \\
(0.134)\end{array}$ & $\begin{array}{c}0.281^{* * *} \\
(0.107)\end{array}$ \\
\hline Lev & $\begin{array}{c}-1.677^{* * *} \\
(0.218)\end{array}$ & $\begin{array}{c}-2.059^{* * *} \\
(0.200)\end{array}$ & $\begin{array}{c}-1.790^{* * *} \\
(0.272)\end{array}$ & $\begin{array}{r}-1.994^{* *} \\
(0.200)\end{array}$ \\
\hline Investment & $\begin{array}{l}-0.004 \\
(0.039)\end{array}$ & $\begin{array}{c}0.120^{* * *} \\
(0.045)\end{array}$ & $\begin{array}{c}0.004 \\
(0.043)\end{array}$ & $\begin{array}{c}0.130^{* * *} \\
(0.048)\end{array}$ \\
\hline DS & $\begin{array}{c}0.440 \\
(0.351) \\
\end{array}$ & $\begin{array}{l}0.873^{* *} \\
(0.380)\end{array}$ & $\begin{array}{c}0.035 \\
(0.368) \\
\end{array}$ & $\begin{array}{c}1.202^{* * *} \\
(0.356)\end{array}$ \\
\hline Observations & 5962 & 5990 & 4631 & 5975 \\
\hline $\operatorname{AR}(1)$ & 0.000 & 0.000 & 0.000 & 0.000 \\
\hline AR (2) & 0.721 & 0.687 & 0.779 & 0.956 \\
\hline Hansen & 0.210 & 0.077 & 0.334 & 0.091 \\
\hline
\end{tabular}

coefficients of Customer and Customer_Learn are significantly positive at the $1 \%$ statistical level, indicating that customer capital significantly improves business performance through organizational learning. For these reasons, the above empirical findings support hypotheses $2 \mathrm{~A}, 2 \mathrm{~B}, 2 \mathrm{C}$, and $2 \mathrm{D}$, that is, organizational learning plays a mediating role in the influence of intelligent capital on enterprise performance.

\section{Conclusions and Future Research}

To the best of our knowledge, this study is among the earliest attempts to explain the intelligent capital on enterprise performance. This paper takes listed companies in the electronics industry in Taiwan from 2006 to 2017 as samples. Financial data, intelligent capital data, and board and supervisor data of the listed companies are manually collected and collated. The influence of intelligent capital on enterprise performance is investigated, and the intermediary effect of organizational learning is analyzed. The research findings of this paper are as follows:

First, the human capital is shown to have a significant positive impact on enterprise performance, indicating that human capital constitutes a key driver of enterprise 
performance. Indeed, human capital of high-tech enterprises in Taiwan has been highly valued by investors, which affects the evaluation of enterprise performance by the capital market. Innovation capital is also demonstrated to exert a significant negative impact on enterprise performance, which indicates that in the short term, the effect of enterprise $\mathrm{R} \& \mathrm{D}$ is nonobvious. As a consequence, a large amount of innovation capital investment cannot be supported, which decreases enterprise performance. In addition, process capital is shown to significantly improve enterprise performance, indicating that the establishment of information management systems and databases augments the enterprise's asset utilization efficiency and reduces the enterprise's internal costs, thus enhancing enterprise performance. The significant positive influence of customer capital on corporate performance also indicates that maintaining a good relationship between enterprises and their customers, suppliers, banks, and governments is conducive to augmenting their future profitability and thus improving corporate performance.

Second, human capital and process capital impart a significant promoting effect on the performance of up-, mid, and downstream enterprises. The former has the greatest influence on midstream enterprises, while the latter has the greatest influence on downstream enterprises. Innovation capital also has a significant promoting effect on the performance of upstream enterprises and a significant restraining effect on the performance of midstream enterprises. Moreover, an increase in customer capital will significantly improve the performance of downstream enterprises and significantly reduce the performance of upstream enterprises. This study argues that enterprises in different industrial chains have varied technical levels, added value, and profitability and have dissimilar requirements for various elements of intelligent capital, which results in heterogeneous effects of various elements of intellectual capital on the performance of upstream and downstream enterprises.

Finally, organizational learning plays an important intermediary role in the relationship between intelligent capital and enterprise performance. Human capital, innovation capital, process capital, and customer capital all significantly improve enterprise performance through organizational learning, which indicates that enterprises give more focus to the value creation function of intellectual capital through continuous organizational learning, which results in increasing enterprise profits, cultivating competitive advantages, and improving enterprise performance. Therefore, enterprises should create a supportive and effective learning atmosphere for individuals, teams, and organizations; stimulate the enthusiasm of employees for learning; and improve their learning ability. Indeed, this intellectual capital factor was demonstrated to significantly promote the improvement of enterprise performance through the intermediary mechanism of organizational learning. Finally, the findings only reflect the setting of the Taiwan electronics industry. Nevertheless, the number of businesses involved in cross-country or cross-sectional Taiwan electronics industry is increasing globally, such as in the USA, Japan, and Asia-Pacific. To address these inherent limitations, future research on cross-country studies of various forms of electronics industry would be worth conducting to determine regional differences in the development of electronics industry activities.

\section{Managerial and Practical Implications}

This study provides intelligent capital to enhance the value of companies in the electronics industry. Intelligent capital is often overlooked in management in many electronics industries in Taiwan, and it is a very important key factor in improving the sustainable operation and performance of enterprises. The most important managerial implication and practical insight are developing positive and strong valuebased intelligent capital. We use the GMM dynamic method to observe the changes of the entire intelligent capital of the enterprise. Most of Taiwan's electronics industry is mainly based on foundry manufacturing, and electronics manufacturers often only see actual profits but do not see the importance of intelligent capital [33].

\section{Data Availability}

Our data come from this TEJ database for listed companies in Taiwan's electronics industry.

\section{Conflicts of Interest}

The authors declare that they have no conflicts of interest.

\section{Acknowledgments}

This research was supported by the Business School of Yulin Normal University, China, under contract MOST G2019SK09.

\section{References}

[1] M. Ramezan, "Intellectual capital and organizational organic structure in knowledge society: how are these concepts related?" International Journal of Information Management, vol. 31, no. 1, pp. 88-95, 2011.

[2] R. M. Engelman, E. M. Fracasso, S. Schmidt, and A. C. Zen, "Intellectual capital, absorptive capacity and product innovation," Management Decision, vol. 55, no. 3, pp. 474-490, 2017.

[3] Y. Li and Z. Zhao, "The dynamic impact of intellectual capital on firm value: evidence from China," Applied Economics Letters, vol. 25, no. 1, pp. 19-23, 2018.

[4] N. Kalio, M. D. Tamunomiebi, and N. Ikenna-Amadi, "Intellectual capital development: the black gold of modern organisation," European Journal of International Management, vol. 11, no. 14, pp. 57-62, 2019.

[5] A. M. Subramanian and V. V. D. Vrande, "The role of intellectual capital in new product development: can it become a liability?" Journal of Operations Management, vol. 65, no. 6, pp. 517-535, 2019.

[6] M. Kozera-Kowalska, "Intellectual capital: ISVA, the alternative way of calculating creating value in agricultural entities-case of Poland," Sustainability, vol. 12, no. 7, p. 2645, 2020. 
[7] T. Guenther and D. Beyer, "Hurdles for the voluntary disclosure of information on intangibles: Empirical results for "new economy" industries," in Proceedings of The 26th Annual European Accounting Association Congress, Seville, June 2003.

[8] M. Subramnniam and M. A. Youndt, "The influence of intellectual capital on the types of innovative capabilities," Academy of Management Journal, vol. 48, no. 3, pp. 450-463, 2005.

[9] S. Iswati and M. Anshori, "The influence of intellectual capital to financial performance at insurance companies in jakarta stock exchange (JSE)," in Proceedings of The The 13th Asia Pacific Management Conference, no. 2, pp. 1393-1399, Melbourne, Australia, July 2007.

[10] R. B. Ahmed, "Intellectual capital and firm performance of US multinational firms," Journal of Intellectual Capital, vol. 4, no. 2, pp. 215-226, 2003.

[11] M. C. Chen, S. J. Cheng, and Y. Hwang, "An empirical investigation of the relationship between intellectual capital and firms' market value and financial performance," Journal of Intellectual Capital, vol. 6, no. 2, pp. 159-176, 2005.

[12] F. Sardo, Z. Serrasqueiro, and H. Alves, "On the relationship between intellectual capital and financial performance: A panel data analysis on SME hotels," International Journal of Hospitality Management, vol. 75, pp. 67-74, 2018.

[13] S. Firer and S. Mitchell Williams, "Intellectual capital and traditional measures of corporate performance," Journal of Intellectual Capital, vol. 4, no. 3, pp. 348-360, 2003.

[14] Y. H. Hsu and W. Fang, "Intellectual capital and new product development performance: the mediating role of organizational learning capability," Technological Forecasting and Social Change, vol. 76, no. 5, pp. 664-677, 2009.

[15] C. Soo, A. W. Tian, S. T. T. Teo, and C. John, "Intellectual capital-enhancing HR, absorptive capacity, and innovation," Human Resource Management, vol. 56, no. 3, pp. 431-454, 2017.

[16] M. Salehi and G. Zimon, "The effect of intellectual capital and board characteristics on value creation and growth," Sustainability, vol. 13, no. 13, pp. 7436-7346, 2021.

[17] L. Edvinsson and M. Malong, Intellectual Capital: Realizing Your Company's True Value by Finding its Hidden Brainpower, Harper Collins Publishers Inc., New York, NY, USA, 1997.

[18] T. Dalwai and M. Salehi, "Business strategy, intellectual capital, firm performance, and bankruptcy risk: Evidence from Oman's non-financial sector companies," Asian Review of Accounting, vol. 29, no. 3, pp. 474-504, 2021.

[19] P. M. Senge, "The fifth discipline: the art and practice of learning organization," Performance Improvement, vol. 30, no. 5, p. 37, 1990.

[20] P. M. Senge, "The learning organization, The encyclopedia of pedagogy and informal," Education, 2018.

[21] W. Köhler, "Primate research center," 2018.

[22] G. P. Huber, "Organizational learning: The contributing processes and the literature," Organization Science, vol. 2, no. 1, pp. 88-115, 1991.

[23] B. Levitt and J. G. March, "Organizational learning," Annual Review of Sociology, vol. 14, no. 1, pp. 319-340, 1998.

[24] M. D. R. Cabrita and N. Bontis, "Intellectual capital and business performance in the Portuguese banking industry," International Journal of Technology Management, vol. 43, no. 1/2/3, pp. 212-237, 2008.

[25] Y. S. Kang and B. Y. Kim, "Ownership structure and firm performance: evidence from the Chinese corporate reform," China Economic Review, vol. 23, no. 2, pp. 471-481, 2012.
[26] R. Mubeen, D. Han, J. Abbas, and I. Hussain, "The effects of market competition, capital structure, and CEO duality on firm performance: a mediation analysis by incorporating the GMM model technique," Sustainability, vol. 12, no. 8, p. 3480, 2020.

[27] P. Staszkiewicz, "Model zysków nadzwyczajnych dla przemysłu chemicznego," Przemys Chemiczny, vol. 1, no. 2, pp. 82-83, 2019.

[28] M. Arellano and O. Bover, "Another look at the instrumental variable estimation of error-components models," Journal of Econometrics, vol. 68, no. 1, pp. 29-51, 1995.

[29] R. Blundell and S. Bond, "Initial conditions and moment restrictions in dynamic panel data models," Journal of Econometrics, vol. 87, no. 1, pp. 115-143, 1998.

[30] J. K. Galbraith, The New Industrial State, Penguin, Harmondsworth, UK, 1969.

[31] D. Collins, E. Maydew, and I. Weiss, "Changes in the valuerelevance of earnings and book values over the past forty years," Journal of Accounting and Economics, vol. 24, pp. 39-67, 1997.

[32] D. J. Teece, G. Pisano, and A. Shuen, "Dynamic capabilities and strategic management," Strategic Management Journal, vol. 18, no. 7, pp. 509-533, 1997.

[33] A. Lotfi, M. Salehi, and M. Lari Dashtbayaz, "The effect of intellectual capital on fraud in financial statements," The TQM Journal, vol. 33, no. 2, p. 0257, 2021. 